\title{
Article
}

Arq Neuropsiquiatr 2010;68(1):76-80

\section{Frequency of depression among patients with neurocysticercosis}

\author{
Sergio Monteiro de Almeida', Solange Aparecida Gurjão²
}

\begin{abstract}
Neurocysticercosis (NCC) is a common central nervous system infection caused by Taenia solium metacestodes. Objective: To investigate the occurrence of depression in patients with calcified NCC form. The study group consisted of 114 patients subdivided in four groups: NCC with epilepsy, NCC without epilepsy, epilepsy without NCC and chronic headache. Method: Depression was evaluated and quantified by the Hamilton Rating Scale for Depression (HRSD-21). Results: Percentage of patients with depression was as follows: group 1 (83\%); group 2 (88\%); group 3 (92\%); group 4 (100\%). The majority of patients had moderate depression. Conclusion: Incidence of depression in all groups was higher than in the general population. It is possible that, in a general way, patients with chronic diseases would have depression with similar intensity. NCC is associated with the presence of depression.
\end{abstract}

Key words: depression, neurocysticercosis, psychiatric disturbs, infectious diseases, neuroinfection.

\section{Depressão em pacientes portadores de neurocisticercose}

\section{RESUMO}

Neurocysticercose (NCC) é uma infecção do sistema nervoso central comum causada por metacestodes da Taenia solium. Objetivo: investigar a ocorrência de depressão nos pacientes com NCC forma calcificada. O grupo de estudo é formado por 114 pacientes subdivididos em quatro grupos: NCC com epilepsia, NCC sem epilepsia, epilepsia sem NCC e cefaléia crônica. Método: A presença de depressão foi determinada e quantificada pela Escala de Depressão de Hamilton (HRSD-21). Resultados: A porcentagem de pacientes com depressão foi: grupo 1 (83\%); grupo 2 (88\%); grupo 3 (92\%); grupo 4 (100\%). A maioria dos pacientes apresentou depressão moderada. Conclusão: A incidência da depressão em todos os grupos foi mais elevada do que na população geral, contudo não houve diferença entre os grupos estudados. É possível que, de uma maneira geral, os pacientes portadores de doença crônica apresentarem a depressão em intensidade similar. NCC está associada com a presença de depressão.

Palavras-chave: depressão, distúrbios psiquiátricos, doenças infecciosas, neurocisticercose, neuroinfecção.

Neurocysticercosis (NCC) is the most common parasitic infection of the human central nervous system $(\mathrm{CNS})^{1}$. It is caused by the larval form of the pork tapeworm Taenia solium. It occurs endemically in rural areas of developing countries in Asia, Africa, Latin America and Central Europe where prevalence rates vary from 0.1 to $4.0 \%$. It may also be found in urban ar- eas of developed countries among specific ethnic subgroups ${ }^{1,2}$. In Brazil, the highest prevalence is in the southeast and south areas. It is more frequent in adults, between the third and fourth decades of life, and there is no predisposition for gender or race ${ }^{3}$.

The clinical picture usually includes seizures and headache. Psychiatric dis- 
turbs are typically present in the course of the disease and were extensively studied by psychiatrists at the beginning of the $20^{\text {th }}$ century ${ }^{4-6}$. Psychiatric syndromes that mimic schizophrenia, major affective disorders and dementia have been reported ${ }^{7}$. Few recent studies have tried to describe the psychopathologies associated with NCC using appropriate instruments for psychiatric assessment ${ }^{8}$.

The objective of this study was to evaluate the presence of depression among NCC patients with the calcified chronic form, as well as to correlate the results with clinical aspects and to compare with other chronic diseases such as epilepsy and chronic headache. There is a huge paucity of information in the medical literature on this topic.

\section{METHOD}

This study was approved by the Hospital de Clínicas, Universidade Federal do Paraná (HC-UFPR) IRB. Participants were selected in the neuroinfection, epilepsy and headache outclinics and neurology infirmaries of HC-UFPR. A total of 114 consecutive unselected patients, 62 women and 52 men, were distributed in the following groups:

\section{Study group}

65 patients with NCC, diagnosed according to the criteria of Del Brutto et al. ${ }^{9}$, with positive cerebrospinal fluid (CSF) immunological assays (IFI and ELISA). NCC was classified in inactive forms according with Sotelo et al. ${ }^{10}$. All 65 patients had calcified intraparenchimatous lesions on $\mathrm{CT}$, and were further subdivided in two groups:

Group 1 - NCC with epilepsy $(n=48)$. All patients have partial complex seizures with secondary generalization, and were under anticonvulsivant drug therapy; CSF:
WBCs (mean \pm SD) $11 \pm 32$ cells $/ \mathrm{mm}^{3}$, median 1.5 cells $/$ $\mathrm{mm}^{3}$; glucose $62 \pm 21 \mathrm{mg} / \mathrm{dL}$, median $59 \mathrm{mg} / \mathrm{dL}$; total protein $52 \pm 56 \mathrm{mg} / \mathrm{dL}$, median $35 \mathrm{mg} / \mathrm{dL}$.

Group 2 - NCC without epilepsy ( $\mathrm{n}=17)$; CSF: WBCs (mean+SD) $19 \pm 48$ cells $/ \mathrm{mm}^{3}$, median 2.1 cells $/ \mathrm{mm}^{3}$; glucose $59 \pm 6 \mathrm{mg} / \mathrm{dL}$, median $56 \mathrm{mg} / \mathrm{dL}$; total protein $129 \pm 274 \mathrm{mg} / \mathrm{dL}$, median $35 \mathrm{mg} / \mathrm{dL}$.

\section{Control group}

49 patients with CT without cysts or calcifications suggestive of NCC were further subdivided in the following two groups:

Group 3 - Patients with history of epilepsy (temporal lobe epilepsy and cryptogenic epilepsy), under anticonvulsive drug at the time of the study, but not associated with NCC $(n=25)$. Patients were not in the post-seizure period.

Group 4 - Patients with history of chronic headache $(n=24)$.

\section{Evaluation of depression}

Depression was evaluated by the Portuguese version of the 21 item Hamilton Rating Scale for Depression (HRSD-21) ${ }^{11}$. The scale was applied by the same researcher in a blind way. Scores above 25 points identify severe depression; between 18 and 24 moderate depression; between 7 and 17 mild depression; and 0 to 6 indicate no depression ${ }^{11}$.

Epidemiological characteristics of the participants in each group are shown in Table 1. Comparing the groups with NCC (groups 1+2) with the groups without NCC (groups $3+4$ ) there is no statistic difference between age,

Table 1. Epidemiological characteristics of participants in each group.

\begin{tabular}{|c|c|c|c|c|c|c|c|c|}
\hline \multirow[b]{2}{*}{ Group } & \multirow[b]{2}{*}{$n$} & \multirow{2}{*}{$\begin{array}{c}\text { Age (years) } \\
\text { (mean } \pm S D)\end{array}$} & \multicolumn{2}{|c|}{ Male } & \multicolumn{2}{|c|}{$\begin{array}{c}\text { At least eight } \\
\text { years of education }\end{array}$} & \multicolumn{2}{|c|}{$\begin{array}{l}\text { Live in } \\
\text { rural area }\end{array}$} \\
\hline & & & $n$ & (\%) & $n$ & (\%) & $n$ & (\%) \\
\hline Group 1 & 48 & $38 \pm 12$ & 24 & 50 & 38 & 79 & 10 & 21 \\
\hline Group 2 & 17 & $40 \pm 12$ & 7 & 41 & 13 & 76 & 13 & 76 \\
\hline Group 3 & 25 & $33 \pm 13$ & 13 & 52 & 20 & 80 & 5 & 20 \\
\hline Group 4 & 24 & $46 \pm 13$ & 8 & 33 & 22 & 92 & 2 & 8 \\
\hline
\end{tabular}

Table 2. Gender distribution of depression scores by the HRSD-21.

\begin{tabular}{|c|c|c|c|c|c|c|}
\hline \multirow[b]{2}{*}{ Score } & \multicolumn{2}{|c|}{ Male } & \multicolumn{2}{|c|}{ Female } & \multirow{2}{*}{$\begin{array}{c}\text { Total } \\
\mathrm{N}\end{array}$} & \multirow[b]{2}{*}{$p$} \\
\hline & $\mathrm{N}$ & $\%$ & $\mathrm{~N}$ & $\%$ & & \\
\hline$>25$ & 8 & 25 & 24 & 75 & 32 & $0.007^{*}$ \\
\hline $18-24$ & 12 & 35 & 22 & 65 & 34 & $0.007^{*}$ \\
\hline 7-17 & 22 & 61 & 14 & 39 & 36 & 0.287 \\
\hline$<7$ & 10 & 83 & 2 & 17 & 12 & - \\
\hline
\end{tabular}


gender and years of education $(\mathrm{p}=0.769 ; 0.594$ and 0.368 respectively). According with the origin of the patient, patients with NCC have higher proportion of participants that lived in rural area, $\mathrm{p}=0.013$ (Table 1).

\section{Statistical method}

Continuous variables were compared using the Kruskal-Wallis and Mann Whitney non-parametric tests. Chi-square and Fisher's exact test was used for qualitative variables. Results are shown as mean plus standard deviation or frequencies and percentage, and significance level (p). A p value $\leq 0.05$ was considered significant.

\section{RESULTS}

Patients with NCC (groups 1 and 2) showed a frequency of depression of $85 \%$ (55/65), and the frequency of depression among the patients without NCC (groups 3 and 4) was 96\% (47/49). There was no difference between the percentage of depression (Fisher's exact test $\mathrm{p}=0.0665 ; \mathrm{MW} \mathrm{p}=0.1394)$. There was no difference between the scores of depression in the groups with NCC and without NCC.

Depression was more frequent in women 97\% (60/62) than in men $81 \%$ (42/52), $\mathrm{p}=0.01$. Scores indicating severe or moderate depression were more frequent in women, while men tend to have mild depression (Table 2).

Frequencies of depression observed in each groups were: group with NCC and epilepsy 83\% (40 patients); group with NCC without epilepsy $88 \%$ (15 patients); group with epilepsy not associated with NCC 92\% (23 patients); group with chronic headache 100\% (24 patients). Scores of depression in the different groups are shown in Fig 1.

Scores (mean \pm SD) of depression by the HRSD-21 in the different groups studied were; group 1, 19 $\pm 11 \%$; group

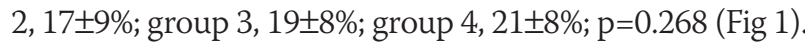

In group 1, 31\% had scores between 18 and 24 (moderate depression); and in group 2, 41.2\% had scores between 7 and 17 (mild depression) (Fig 2).

\section{DISCUSSION}

Studies evaluating depression in NCC patients are scarce. In this study, we observed a frequency of depression in groups with NCC of $83 \%$ and $88 \%$. There was no statistical difference in the frequency of depression between NCC patients and patients of other chronic neurological diseases prevalent in the general population, such as epilepsy and headache.

Very few publications have considered the psychiatric manifestations of NCC, most of them consisting of case reports of neurological studies with detailed clinical and pathological descriptions. Some studies on NCC published in the beginning of $20^{\text {th }}$ century were performed with inpatients from psychiatric hospitals ${ }^{4-6}$.

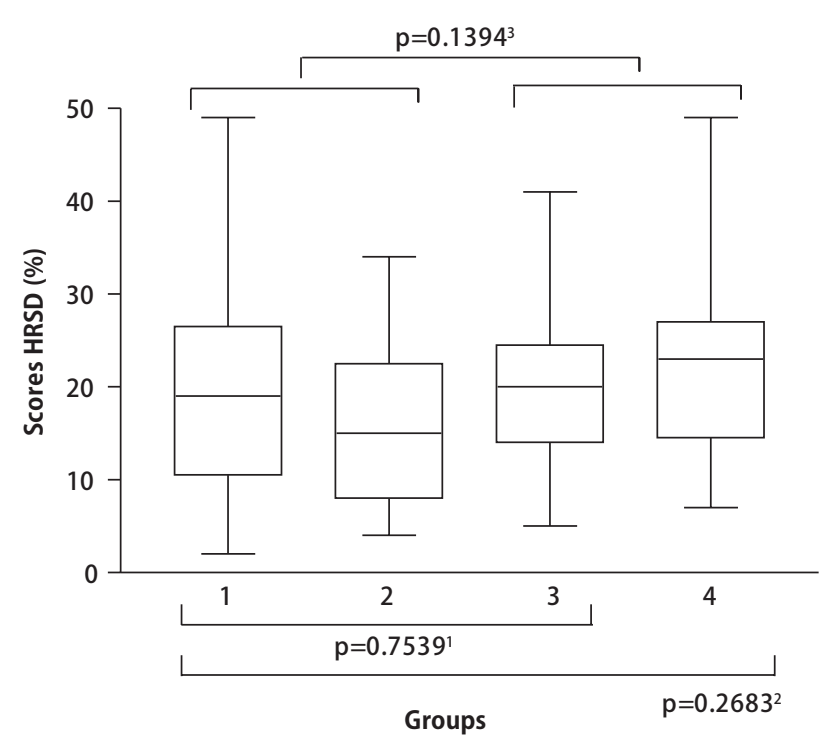

Fig 1. Scores of depression by the HRSD-21 in the different groups. (1) Group 1 compared with group 3; (2) All four groups compared; (3) Groups 1 and 2 compared with groups 3 and 4 .

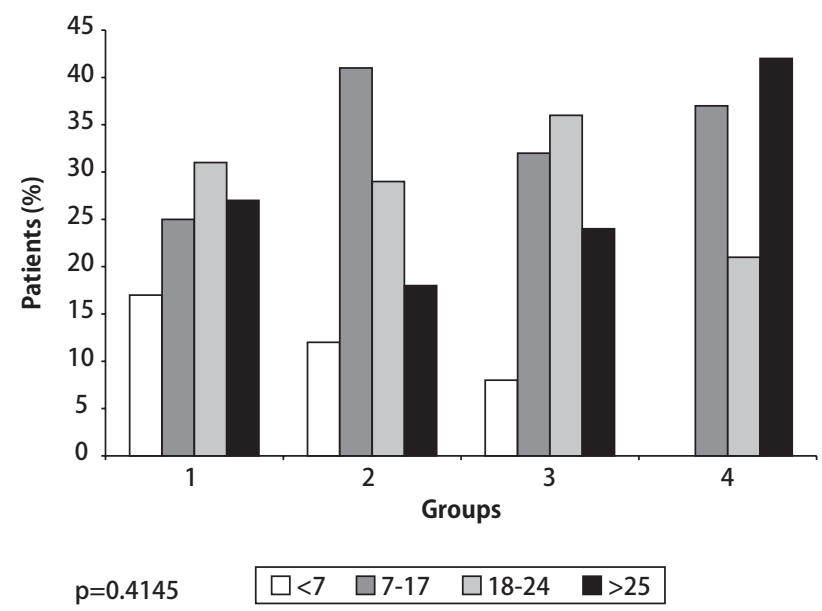

Fig 2. Distribution of scores of depression by the HRSD-21 in the different groups.

The incidence of depression in all groups studied was higher than in the general population. In Brazil, the annual prevalence of depression is not well known, but it is considered to be between $3 \%$ and $11 \%$ in the general population ${ }^{12,13}$, and about $10 \%$ among patients of primary health care ${ }^{14}$. Among inpatients with any physical illness depression prevalence was found to be between $22 \%$ and $33 \%{ }^{15}$. Approximately $80 \%$ of patients that received treatment for a depressive episode will have a second episode throughout their lives ${ }^{16}$.

In this study depression was three times more frequent in women; this is in agreement with previous studies ${ }^{15}$.

In a previous study with NCC patients, depression was the most frequent psychiatric diagnosis in $53 \%^{8}$. Psy- 
chiatric diagnoses were made by the Present State Examination and the Schedule for Affective Disorders and Schizophrenia. Active disease and intracranial hypertension were associated with higher psychiatric morbidity, and previous history of mood disorders was strongly related to current depression ${ }^{8}$. However, this study did not have a control group. The incidence of depression found in our study is higher probably due to the small size of the groups, although we cannot rule out population characteristics or differences in the psychiatric instrument used for the evaluation.

NCC is a common disease all around the world, and is considered endemic in Brazil ${ }^{17}$. It is common in both genders, in all ethnic groups and all ages, but with predominance between 11 and 35 years ${ }^{1,17}$.

The most frequent clinical manifestations of NCC are seizures (62\%), intracranial hypertension syndrome (38\%), and meningitis $(35 \%)^{18}$. There is a high frequency of asymptomatic patients and brain calcifications due to NCC in endemic areas ${ }^{1,3,17,18}$. In our study, all cases with NCC have intra-parenchyma calcifications.

NCC is a leading cause of seizures and epilepsy in the developing world and is an increasingly important health issue in developed countries, such as the United States. Because millions of people have immigrated from Latin America in recent years, NCC has become an increasingly important cause of seizures in the United States ${ }^{19}$. For example, between 1994 and 1998, an average of 120 patients with cysticercosis were admitted to the Los Angeles County/USC Medical Center per year ${ }^{20}$. These numbers represent a substantial increase from 1983, when 80 cases were identified in all four Los Angeles County hospitals ${ }^{21}$. Cysticercosis now accounts for up to 10\% of emergency room visits for seizures in the southwestern United States ${ }^{19}$.

Due to population migration from endemic areas, cysticercosis also has importance as a traveler's disease ${ }^{19,21}$.

In the present study, the frequency of depression in groups with epilepsy (groups 1 and 3) was 86\%, higher than described in the literature. However, a comparison between group 1 (an association of two factors, NCC and epilepsy) and groups 2 and 3 reveals that the incidence of depression was not higher nor there was higher number of cases with more severe depression levels in groups 2 and 3 .

The prevalence of interictal depressive illness in epileptic patients is between $50 \%$ and $60 \%{ }^{22,23}$. Other studies have shown a frequency of up to $75 \%$ of depression in groups of epilepsy and an increase of depressive symptoms in epileptic patient when compared to normal control ${ }^{24,25}$.

When patients receive the diagnosis of epilepsy, some can react with a period of sadness before the adaptation. After elaborating this situation, they tend to come back to the normal mood. However, there are those that develop a depressive picture with morbidity characteristics.
The physician must differentiate between a depression of organic characteristics or a psychogenic reactive depression, or one without pathological characteristics. The depression, then, can be concomitant to, precede, or follow the epileptic picture ${ }^{26}$. Post-ictal depressive episodes must also be considered, which disappears in few hours.

In this study, the group with epilepsy had a higher number of moderately depressed patients and in the group of NCC without epilepsy $41.2 \%$ were slightly depressed.

The group with chronic headache had a higher number of patients seriously depressed, (42\%), in agreement with previous studies ${ }^{27}$. These authors demonstrated that these patients have significant limitations in life quality relative to the healthy population and when compared with other chronic illnesses, such as arthrosis and diabetes.

The analyses of the scores of depression did not present significant difference between groups of NCC and other groups. It is possible that, in a general way, patients with a chronic illness will have depression in a similar intensity. In chronic conditions, the emotional, familiar, social, physical and functional aspects are compromised, influenced by the type and degree of illness compromise, and period of the illness.

The risks and factors contributing to major depressive episodes in NCC infection remain unclear. The immunologic response and incidence of depression in NCC must be evaluated. There is a strong suggestion that cytokines have a role in the biology of depression ${ }^{28}$. Th1 cytokines are predominant in the immunological response elicited by Cysticercus cellusae and include gamma interferon, interleukin-18 (IL-18), and the immunosuppressive, fibrosis-promoting cytokine transforming growth factor beta. The Th2 cytokines IL-4, IL-13, and IL-10 ware also present, though to a lesser extent ${ }^{29,30,31}$. Monocyte stimulation by T. solium larval antigen results in a differential secretion profile of chemokines: CCL3/MIP-1alpha after 8 hours, CXCL8/IL- 8 after 24 hours, and CCL2/MCP-1 after 48 hours $^{32}$. Some of these immunological factors are described when depression is associated with infectious diseases such as $\mathrm{HIV}^{33}$ and $\mathrm{HCV}^{28}$.

Although immunological factors could be related with the development of depression, higher frequencies were found, in our study, in groups without infectious diseases such as epilepsy and chronic headache. These data lead us to hypothesize about the association of other factors such as genetic predisposition, or social and cultural factors. Patients with chronic illnesses possess peculiarities that must be considered in the evolution of the disease and its treatment, such as presence of depressive phenomena or anxiety on a large scale, beside acute reduction or loss of work capacity that will interfere in life quality. This study have some limitations: the participants were not evaluated by a psychiatrist, other psychiatric diagnosis instru- 
ments as DSM-IV criteria, MINI plus or SCID were not used. Previous personal or family psychiatric story including depression story or anti-depressive medication use was not collected. Delirium was not evaluated. No information about the use of prophylactic pain medication as tricyclic antidepressants was collected. Cognitive status, alcohol or substance abuse was not assessed. There are few studies addressing the topic depression among patients with NCC, besides the limitations of the study this association is shown; although other studies are necessary for definitive conclusions.

\section{REFERENCES}

1. Del Brutto OH, Sotelo J. Neurocysticercosis: an update. Rev Infect Dis 1988;10: 1075-1087.

2. De Giorgio CM, Sorvillo F, EscuetaSP, Wallin MT, Kurtzke JF. Neurocysticercosis in the United States: review of an important emerging infection. Neurology 2005;64:1486.

3. Andrade-Filho AS, Souza APQU, Souza YMA. Neurocisticercose. Revisão. Parte I. Revista Brasileira de Neuro-Psiquiatria 1997;1:125-130.

4. Bastos FO. Aspectos psiquiatricos da neurocisticercose. Rev Paul Med 1953;43: 162-164.

5. Pupo PP, Cardoso W, Reis JB, Silva CP. Sobre a cisticercose encefálica: estudo clínico, anátomo patológico, radiológico e do LCR. Arq Assist Psicopatol 1945/1946;10/11:3-123.

6. Tretiakoff C, Pacheco e Silva AC. Contribuição para o estudo da cysticercose cerebral e em particular das lesões cerebraes tóxicas a distancia nesta affecção. Mem Hosp Juqueri 1924;1:37-66.

7. Ramirez-Bermudez J, Higuera J, Sosa AL, Lopez-Meza E, Lopez-Gomez M, Corona T. Is dementia recersible im patients with neurocysticercosis? J Neurol Neurosurg Psychiatry 2005;76:1164-1166.

8. Forlenza OV, Vieira AHG, Nobrega JPS, et al. Psychiatric manifestations in neurocysticercosis: a study of 38 patients from a neurology clinic in Brazil. J Neurol. Neurosurg Psychiatry 1997;62:612-616.

9. Del Brutto OH, Rajshekhar V, White AC Jr, et al. Proposed diagnostic criteria for neurocysticercosis. Neurology 2001;24;57:177-183.

10. Sotelo J, Guerrero V, Rubio F. Neurocysticercosis: a new classification based on active and inactive forms. A study of 753 cases. Arch Intern Med 1985; 145:442-445.

11. Hamilton M. Rating scale for depression. J Neurol Neurosurg Psychiatry 1960; 23:56.

12. Jenkins R, Lewis G, Bebbington P, et al. The National Psychiatric Morbidity Survey of Great Britain: initial findings from the household surveys. Psychol Med 1997;27:775-789.

13. Kessler RC, McGonagle KA, Zhao S, et al. Lifetime and 12-month prevalence of DSM-IIIR psychiatric disorders in the United States. Arch Gen Psychiatry 1994;51:8-19.
14. Ustun TB, Sartorius N (Eds). Mental illness in primary care: international study. New York:John Wiley \& Sons, 1995.

15. World Psychiatric Association. Educational program on depressive disorders. Overview and fundamental aspects. New York: NCM, 1997.

16. Anderson IM. Selective serotonin reuptake inhibitors versus tricyclic antidepressants: a metaanalysis of efficacy and tolerability. J Affect Disord 2000; 58: 19-36.

17. Takayanagui OM, Jardim E. Therapy for neurocysticercosis: comparison between albendazole and praziquantel. Arch Neurol 1983;49:290-294.

18. Garcia HH, Del Bruto OH. Neurocysticercosis:updated concepts about an old disease. Lancet Neurol 2005;4:653-661.

19. Ong S, Talan D, Moran, G, et al. the Emergencyt IDNET Study Group. Neurocysticercosis in radiographically imaged seizure patients in U.S. emergency departments. Emerg Infect Dis 2002;8:608-613.

20. Ko D. Seizures in neurocysticercosis at LAC+USC Medical Center. Epilepsia 2003;44:15

21. Richards FO, Schantz PM, Ruiz-Tiben E, Sorvillo FJ. Cysticercosis in Los Angeles County. JAMA 1985;254:3444-3448.

22. Mendez MF, Cummings $J$, Benson DF. Depression in epilepsy: significance and phenomenology. Arch Neurol 1986;43:766-770.

23. Indaco A, Carrieri PB, Nappi C, Gentile S, Striano S. Interictal depression in epilepsy. Epilepsy Res 1992;12:45-50.

24. Bear D, Fedio P. Quantitative analysis of interictal behavioral in temporal lobe epilepsy. Arch Neurol 1977;34:454-467.

25. Robertson MM. Depression in patients with epilepsy: an overview. Semin Neurol 1991;11:182-189.

26. Currie S, Heathfield KWH, Henson RA., Scott DF. Clinical course and prognosis of temporal lobe epilepsy; a survey of 666 patients. Brain 1971;94:173-190.

27. Bigal ME, Fernandes LC, Moraes FA, Bordini CA, Speciali JG. Prevalência e impacto da migrânea em funcionários do HC da Faculdade de Medicina de Ribeirão Preto - USP. Arq Neuropsiquiatr 2000;58:431-436.

28. Loftis JM, Huckans M, Ruimy S, Hinrichs DJ, Hauser P. Depressive symptoms in patients with chronic hepatitis $C$ are correlated with elevated plasma levels of interleukin-1 beta and tumor necrosis factor-alpha. Neurosci Lett 2008;430: 264-268.

29. Restrepo Bl, Alvarez Jl, Castaño JA, et al. Brain granulomas in neurocysticercosis patients are associated with a Th1 and Th2 profile. Infect Immun 2001;69: 4554-4560.

30. Chavarría A, Fleury A, García E, Márquez C, Fragoso G, Sciutto E. Relationship between the clinical heterogeneity of neurocysticercosis and the immuneinflammatory profiles. Ciln Immunol 2005;116:271-278.

31. Aguilar-Rebolledo F, Cedillo-Rivera R, Llaguno-Violante P, Torres-López J, Muñoz-Hernandez O, Enciso-Moreno JA. Interleukin levels in cerebrospinal fluid from children with neurocysticercosis. Am J Trop Med Hyg 2001;64:35-40.

32. Uddin J, Gonzalez AE, Gilman RH, et al. Neurocysticercal antigens stimulate chemokine secretion from human monocytes via an NF-kappaB-dependent pathway. Microbes Infect 2006:8:1732-1740.

33. Atkinson JH, Heaton RK, Patterson TL, et al. Two-year prospective study of major depressive disorder in HIV-infected men. J Affect Disord 2008;108: 225-234. 